\title{
Breast Reconstruction with Non-Abdominal Autologous Tissue
}

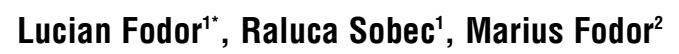 \\ 'Department of Plastic Surgery, Emergency County Hospital, Cluj-Napoca \\ ${ }^{2}$ Vascular Surgery Department, Emergency District Hospital, Cluj Napoca
}

*Corresponding author: Lucian Fodor, MD, PhD Department of Plastic Surgery Emergency County Hospital Clinicilor 3-5, Cluj-Napoca 400006, Romania

E-mail: office@drfodor.ro

\section{Rezumat}

Reconstrucția de sân cu țesut autolog din afara regiunii abdominale

Progresele chirurgicale în domeniul reconstrcuțiilor de părți moi sunt remarcabile. Tehnicile de reconstrucție de sân au evoluat în ultimii 40 de ani. Tendința a fost de a migra de la lambourile pediculate către lambourile libere. În literatura engleză au fost publicate diverse lambouri libere pentru reconstrucția de sân. Deşi lamboul DIEP este veteranul reconstrucției, sunt pacienți care nu au suficient țesut abdominal pentru a fi folosit. În aceste cazuri, alte zone donatoare cum sunt regiunea fesieră, coapsă sau regiunea lombară pot fi folosite pentru reconstrucție. Articolul prezent descrie metodele de reconstrucție de sân folosind țesutul nonabdominal.

Cuvinte cheie: reconstrucția de sân, lambouri libere, lamboul gluteu, lamboul gracilis

\section{Abstract}

The progresses in surgical field are amazing regarding the possibilities of soft tissue reconstruction. Techniques of breast reconstruction have been evolved since the last 40 years. There was a trend from pedicled flaps toward microsurgical free flaps. In the English literature have been reported several types of free flaps for BR. Although DIEP is the workhorse for the reconstruction, there are patients that do not have enough abdominal tissue to use. In those cases, other donor area such as buttock, thigh, lumbar area has been reported. The present article describes the choices for BR with non-abdominal autologous tissue. 
Key words: breast reconstruction, free flaps, gluteal flaps, Gracilis flap

\section{Introduction}

Breast reconstruction techniques evolved in the last years (1). Overall breast reconstruction with autologous tissue techniques evolved from pedicle flaps to free flaps. A free flap is a tissue transfer using microsurgical techniques. In ourdays the free flaps are the workhorse for most of the surgeons performing breast reconstruction (BR). A step forward for this evolution was the importance of microsurgical advances. The free flap survival rate for $\mathrm{BR}$ has been reported as high as $95-98 \%$ in different studies(2-4). Due to high success rate, there were progresses of reconstruction. The autologous free tissue transfer is the primary choice in many centers because it is a successful and reliable technique (5).

The advantages of breast autologous reconstruction include better symmetry and less revisions. The free flaps for $\mathrm{BR}$ can be categorized intoabdominal and non- abdominal types. Although the Deep Inferior Epigastric Free flap (DIEP) is the most popular and frequently used flap, secondary options include: Gluteal artery perforator flaps, Transverse upper gracillis, Fasciocutaneousinfragluteal flap and lumbar artery perforator flap.

There are several factors that affect the flap choice. The contralateral breast in regard of volume and shape as well as patient choice are important in choosing the donor area. Patients without abdominal fat excess seems to be good candidates. Patients with previous abdominal scars or abdominal liposuction can benefit from non-abdominal free flaps. Woman's choice regarding the donor area is an important factor in choosing the flap. It is now widely accepted that most anastomoses are performed at the internal mammary vessels which are suitable for anastomoses (6-8). The caliber matches with most free flaps pedicle. The thoracodorsal vessels are the back up for the anastomoses.
Over the past 12 years we have performed 159 free flaps autologous breast reconstruction.

128 DIEP were for unilateral breast reconstruction, six DIEP were for bilateral breast reconstruction and 25 were alternative free flaps (FCI, SGAP and IGAP). Each autologous free flap design and map perforator is done using a Doppler sound the day before surgery (Fig. 1A). During the flap harvesting, the large perforators are located. In most cases single or double perforators (Fig. $1 \mathrm{~B}, \mathrm{C}$ ). Once the perforator is chosen, the dissection starts intramuscular to the deep part and toward the inferior epigastric vessels. The recipient vessels are the internal mammary. The complete technique of DIEP flap is detailed in another article of the same volume. Most of the time these patients requires a second stage for breast simmetrization, either on the flap side or the contralateral side (Fig. 3A-C, Fig. 4A, B).

Complete flap necroses was encountered in five cases $(3.14 \%)$. The most frequent minor complication encountered was abdominal seroma, especially in obese patients. Other minor complications were: bleeding, marginal flap necroses, donor area infection and wound dehiscence. These minor complications did not jeopardized the flap viability.

\section{Gluteal Artery Perforator Flaps}

There are two type of flaps based on gluteal artery perforators. The Superior Gluteal Artery Flap (SGAP) is based on perforators coming to the skin in the upper part of the gluteal area (Fig. 4A). The Inferior Gluteal Artery Flap (IGAP) is based in the perforators coming from this vessel and are located in the lower gluteal area.

The superior gluteal artery is the terminal branch of the posterior part of internal iliac artery. Most perforators are in the upper part of the superior gluteal artery. Preoperative the perforators are located using a Doppler sound. 

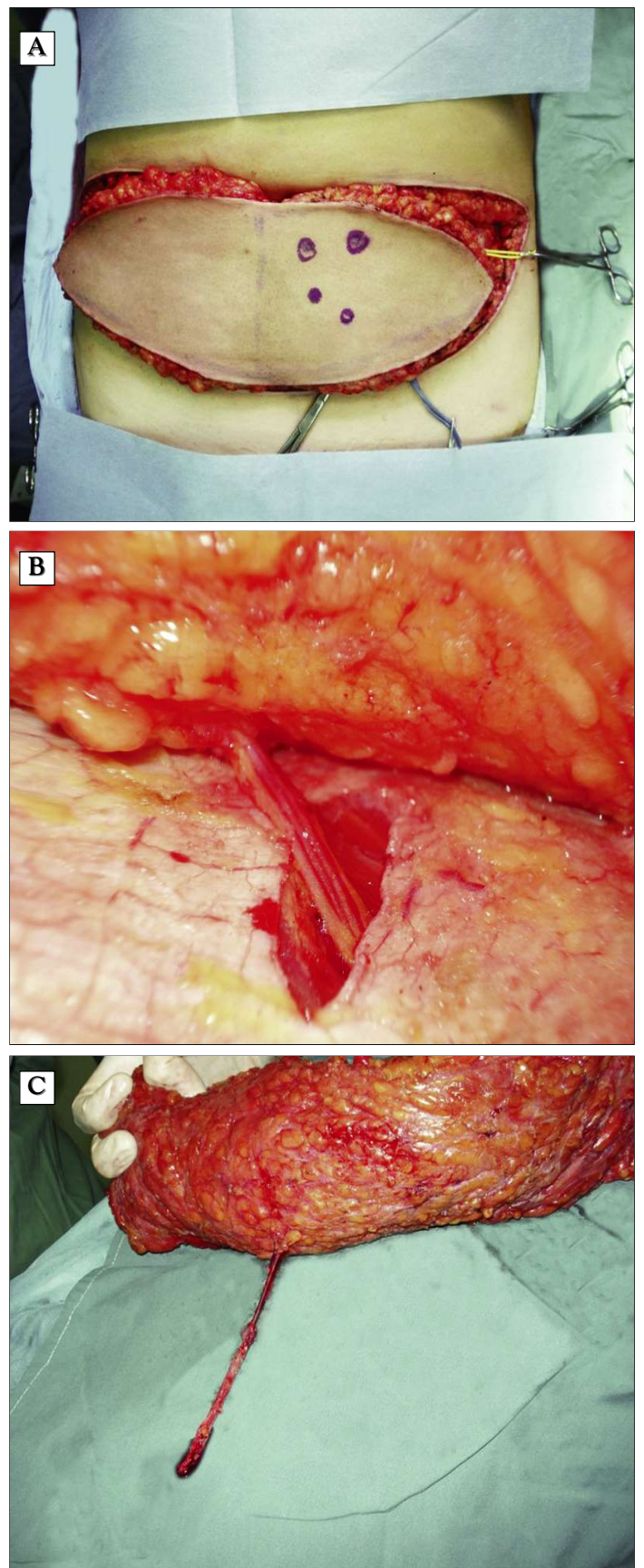

Figure 1. (A) The flap and perforator mapping; (B) The perforator artery and the two comitante veins are dissected inside the muscle; (C) The single perforator is harvested in most cases
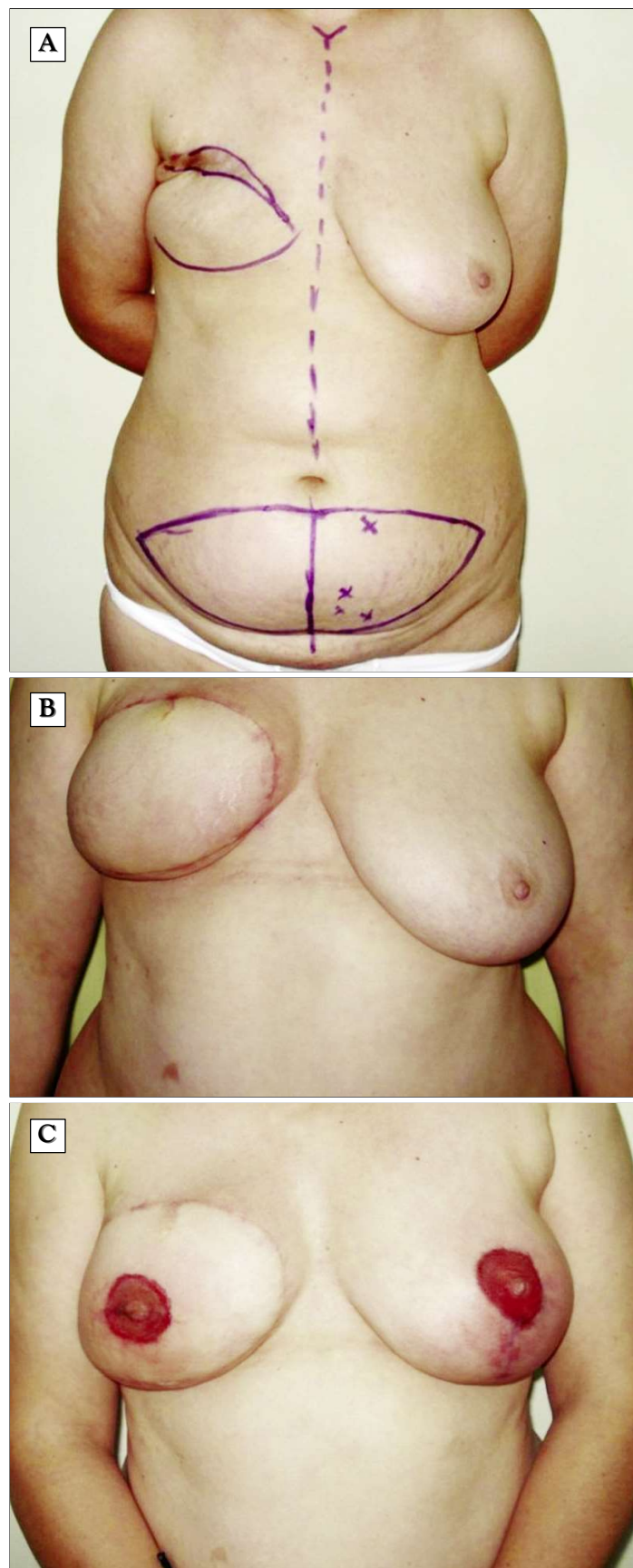

Figure 2. (A) The design of the flap before surgery;

(B) The aspect six month after surgery and before second step. (C) The final result after simmetrization and nipple areola reconstruction
CT angiography can be usedto locate the perforators in any free flap used for BR.

The patient is placed on the lateral or supine position and the skin paddle is harvested. Large skin paddle have been reported , with size from 10 to $22 \mathrm{~cm} 3(9)$. Beveling inci- sion is preferred to harvest more fat. The dissection proceeds from lateral to medial. Lateral perforators are preferred because longer pedicle can be achieved. Once the supramuscular perforators are located, the dissection goes deep into the muscle following 

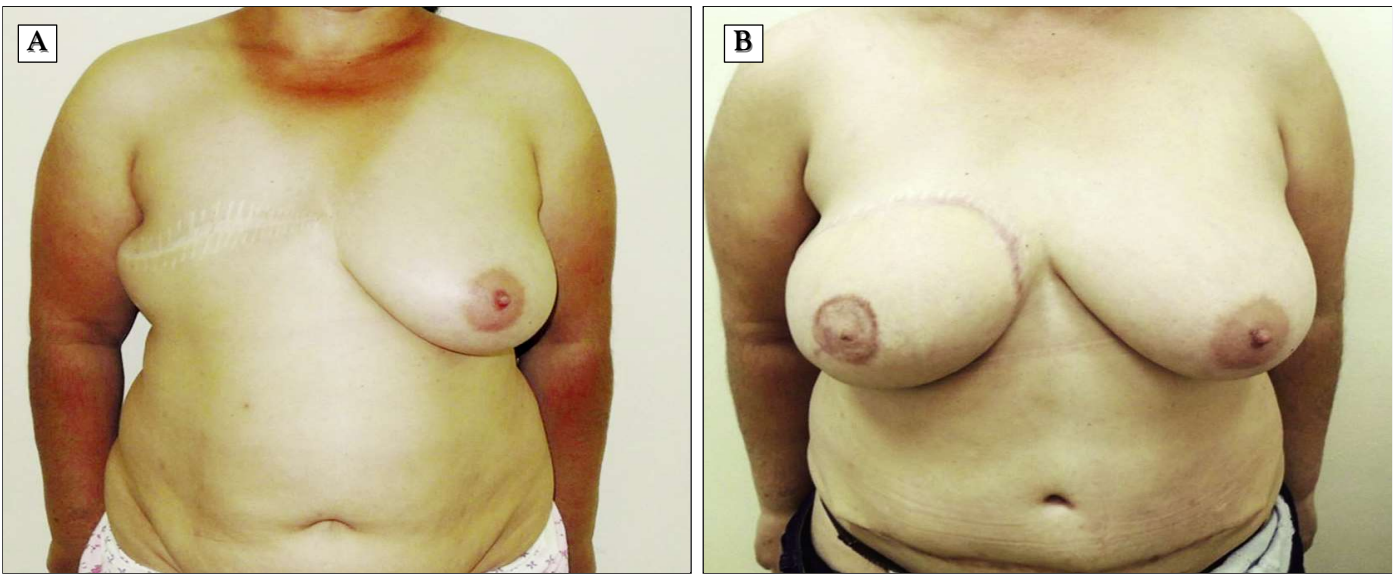

Figure 3. (A) Before surgery; (B) Final result after large flap harvesting on two perforators
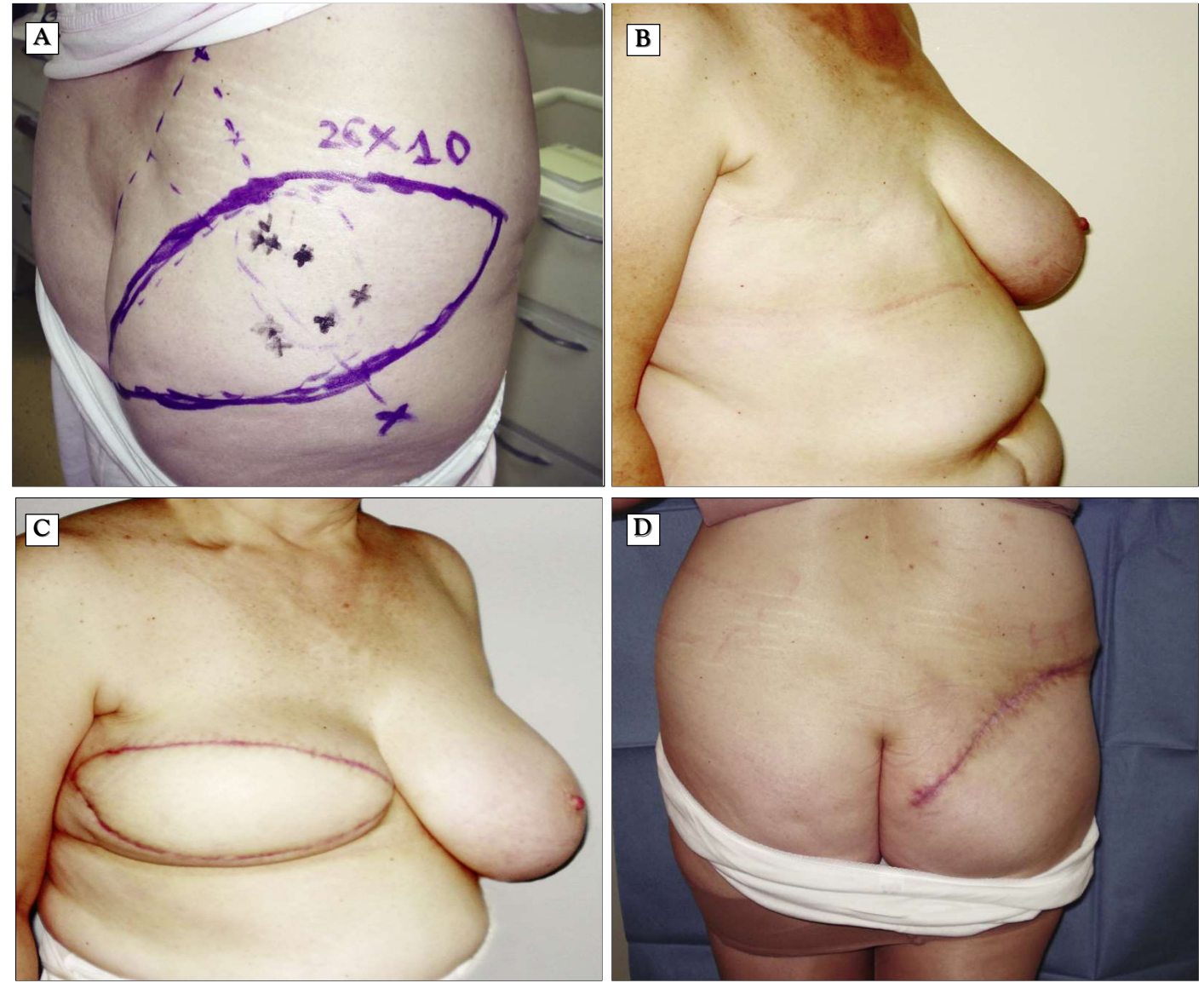

Figure 4. (A) Preoperative perforator mapping with Doppler ultrasound; (B) Preoperative view after mastectomy; (C) Postoperative aspect after SGAP fla; (D) Although the scar is hidden inside the underwear, the donor area volume is changes in cases with large flap

the perforator to the main branch. Single large perforator is enough to supply the flap. The artery size and length are the limiting step of the dissection. The pedicle diameter varies from 2 to $3 \mathrm{~mm}$. Ligating clips are especially useful in the deeper dissection area. Once the flap is elevated the donor area is primary closed over the drainage. The patient is placed 
supine and the anastomoses are performed to the internal mammary vessels (10).

The IGAP flap is usually designed with the patientorthostatic. The lower limit of the flap is usually $1-2 \mathrm{~cm}$ above the infragluteal crease and skin paddle is parallel with it. The vessels are preoperative located with a Doppler sound most frequently. Similar patient position as for SGAP is used for flap harvesting. The same principles of dissection are applied. The gluteus muscle is preserved and the largest perforator is usually dissected deep into the muscle to the inferior gluteal vessels $(11,12)$. The donor area is primary closed over a drainage tube. The pedicle length is $7-10 \mathrm{~cm}$.

SGAP and IGAP flaps are indicated for women with previous abdominal scars, nulliparous, those who have nipple or areola sparing mastectomies. The disadvantages are the necessity to change the patient position, donor area deformation in case of large flap harvesting (Fig. $4 A-D$ ), local pain, and high risk of dehiscence.

\section{Fasciocutaneous Infragluteal Flap (FCI)}

The FCI flap is based on terminal branches of the inferior gluteal artery. The vessels exit through the infrapiriform aperture and the descending branch runalong the posterior femoral cutaneous nerve of the thigh. At the level of the infragluteal area, there are anastomoses with perforators from profunda femoris, obturator artery forming so called cruciate anastomosis $(13,14)$. Before surgery, the patient is placed on prone position with a roll under the hips and the perforator is in the gluteal crease. Most of the time it is found near middle of the crease. The skin paddle is drawn according to the breast measurements and it always include the crease. The dissection starts in the upper part and it goes bevelto include more fat. Once the dissection reach the muscle, it continues caudal with ligation of perforator muscles. Closer to the crease, perforators coming immediately under the gluteus are joined by sensitive branches. The dissection on the caudal part of the flapshould be cautious due to the presence of posterior femoral cutaneous nerve. On the medial aspect, it is recommended to preserve some fat around the ischium to avoid pressure sores. The dissection is performed under the gluteus muscle with preservation of the sciatic nerve which is next to the pedicle. Muscle relaxants are helpful in performing the deeper dissection. Ligating clips are especially useful for the proximal dissection. The pedicle can reach $12-18 \mathrm{~cm}$ length (15). Due to the cruciate anastomosis, more fat from the surroundings can be harvested $(16,17)$. The donor area is primary closed and the patient is instructed to avoid complete forward bending in the coming weeks.

The flap is indicated in women without abdominal fat deposits, in those who have a small to medium size of the contralateral breast. In patients who have buttock lipodystrophy, the flap size can be significantly high (Fig. $5 \mathrm{~A}-\mathrm{D}$ ). The scar is concealed, and it does not distort the donor area. The flap difficult dissection is one of the main drawbacks of it.

\section{Transverse Upper Gracilis Flap (TUG)}

This flap is designed with patient in standing position. By grasping the upper inner thigh between fingers, it can be estimated the amount of tissue and skin that can be used. An average of 8-10 cm skin width can be taken $(18,19)$. The skin island should not overcome the posterior thigh midline, avoiding this the risk of necrosis (20). The flap pedicle dissection is likegracilis flap harvesting. The pedicle dissection should go under the adductor longus muscle in order to get enough length and to facilitate the flap inset $(21,22)$. Comparing with other flap, the dissection is fast. Can be used for bilateral BR (23).

This flap is a useful tool for patients with small - medium size desired breast. Patients with lipodystrophy of the inner thigh and those who lost weight are good candidates for $\mathrm{BR}$ with this technique. The scar is most of the time hidden in the inguinal area. It does not require changing patient position during surgery. The surgery can be performed by two teams simultaneous. 

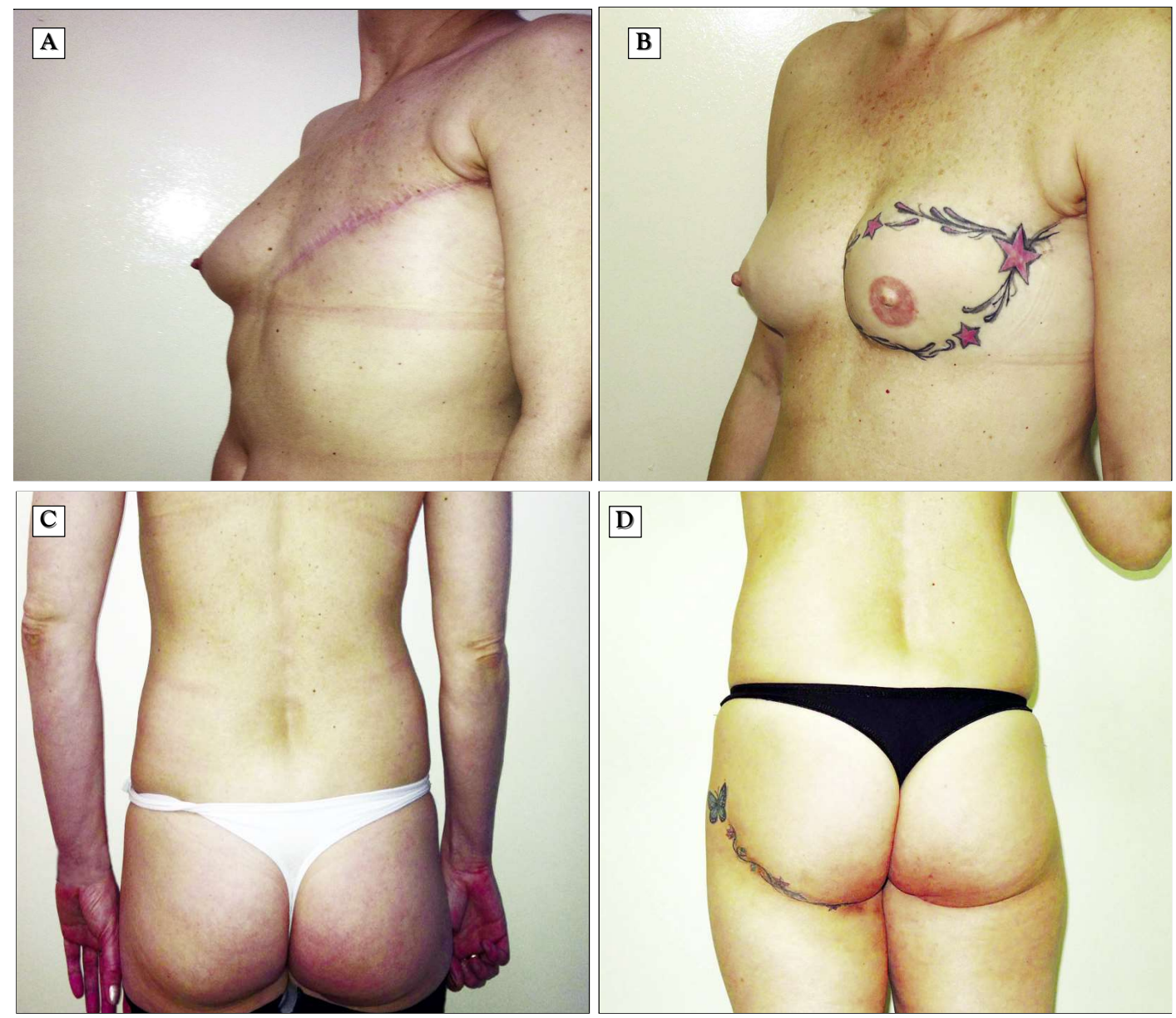

Figure 5. (A) Before breast reconstruction with $\mathrm{FCl}$; (B) After FCl flap and nipple reconstruction; (C) The donor area before flap harvesting; (D) The hidden scar of the donor area after flap harvesting

\section{The Lumbar Artery Perforator Flap (LAP)}

The lumbar area has the advantage of having significant fat tissue. The flap can be harvested on prone or lateral position. Larger flaps of $27 \mathrm{~cm}$ based on single perforator have been reported(24-26). The distribution of perforators is relatively constant, thing that makes this flap reliable(26). Most authors prefer to start the dissection on the lateral and inferior part of the flap. The dissection is on top of the iliac crest and proceeds from lateral to medial. The lumbar perforators are identified coming through the fascia. The dissection continues on the deep part between quadratus lumborum and the paravertebral muscles(27). Although pedicles of $7 \mathrm{~cm}$ length have been reported, the deeper dissection is difficult and it can be risky due to possible nerve injuries at the transverseprocessus (28). It is recommended to stop the dissection once the pedicle reach $4 \mathrm{~cm}$ and to use grafts. The most common grafts used are the deep inferior epigastric vessels (29). The donor area is closed primary.

The advantage of the flap is the large soft tissue that can be harvested. However, the pedicle length is short, and it require grafts to complete the anastomoses. Not all the patients accept the scar in the lombar area.

Other free flaps such as Transverse rectus abdominis muscle (TRAM), superficial inferior epigastric artery (SIEA) and thoracodorsal artery perforator flap (TDAP) are not so frequently used for BR $(30,31)$. 


\section{Conclusions}

According to our experience, DIEP remains the main workhorse for the autologous breast reconstruction. Alternative flaps from buttock (FCI, SGAP and IGAP) are options in patients without significant abdominal fatty tissue. They require patient change position during surgery. Among alternative flaps the FCI has the advantage of very hidden donor area especially in women with some degree of buttock ptosis.

The development in microsurgery and supramicrosurgery allowed significant progresses in BR techniques. There are developing software for three-dimensional breast volume assessment which will allow better planning and symmetry. Tissue engineered reconstruction will significantly affect the surgical methods. However, we are far from significant results in the BR with tissue engineering.

\section{Conflict of Interest}

The authors declare no conflicts of interests.

\section{Ethics Approval}

All procedures involving human participants were in accordance with the ethical standards of the 1964 Helsinki Declaration.

\section{References}

1. Homsy A, Rüegg E, Montandon D, Vlastos G, Modarressi A, Pittet B. Breast Reconstruction: A Century of Controversies and Progress. Ann Plast Surg. 2018;80(4):457-463

2. Zhao R, Tran BNN, Doval AF, Broadwater G, Buretta KJ, Orr JP, et al. A Multicenter Analysis Examining Patients Undergoing Conversion of Implant-based Breast Reconstruction to Abdominally based Free Tissue Transfer. J Reconstr Microsurg. 2018;34(09):685-691

3. Granzow JW, Levine JL, Chiu ES, Allen RJ. Breast reconstruction using perforator flaps. J Surg Oncol. 2006:94:441-454.

4. Beckenstein MS, Grotting JC. Breast reconstruction with free-tissue transfer. Plast Reconstr Surg. 2001;108(5):1345-1353.

5. Champaneria MC, Wong WW, Hill ME, Gupta SC. The evolution of breast reconstruction: A historical perspective. World J Surg. 2012;36:730-742.

6. Ninkovic M, Anderl H, Hefel L, Schwabegger A, Wechselberger G. Interna mammary vessels: a reliable recipient system for free flaps in breast reconstruction. Br J Plast Surg. 1995;48:533-539

7. O'Neill AC, Hayward V, Zhong T, Hofer SOP. Usability of the internal mammary recipient vessels in microvascular breast reconstruction. J. Plast. Reconstr. Aesthetic Surg. 2016;69(7):907-911.

8. Hefel L, Schwabegger A, Ninkovic M, Wechselberger G, Moriggl B, Waldenberger $\mathrm{P}$, et al. Internal mammary vessels: anatomical and clinical considerations. Br J Plast Surg. 1995;48:527-532

9. Lotempio MM, Allen RJ. Breast reconstruction with SGAP and IGAP flaps. Plast Reconstr Surg. 2010;126(12):393-341.

10. Werdin F, Peek A, Martin NCS, Baumeister S. Superior gluteal artery perforator flap in bilateral breast reconstruction. Ann Plast Surg. 2010;64(1):17-21.

11. Heitmann C, Levine JL, Allen RJ. Gluteal Artery Perforator Flaps. Clin Plast Surg. 2007;34(1):123-130.

12. Mirzabeigi MN, Au A, Jandali S, Natoli N, Sbitany H, Serletti JM. Trials and tribulations with the inferior gluteal artery perforator flap in autologous breast reconstruction. Plast Reconstr Surg. 2011;128(6):614e-626e

13. Tan BK, Terence G, Wong CH, Sim R. Lower gluteal muscle flap and buttock fascio-cutaneous rotation flap for reconstruction of perineal defects after abdomino-perineal resections. J Plast Reconstr Aesthetic Surg. 2012; 65(12):1678-1683

14. Hallock GG. The random upper posterior thigh fasciocutaneous flap. Ann Plast Surg. 1994;32(4):367-71.

15. Papp C, Windhofer $C$, Michlits W. Autologous breast augmentation with the deepithelialized fasciocutaneous infragluteal free flap: A 10-year experience. Ann Plast Surg 2011;66(6):587-592.

16. Schoeller T, Huemer GM, Kolehmainen M, Otto-Schoeller A, Wechselberger G. A new "siamese" flap for breast reconstruction: The combined infragluteal-transverse myocutaneous gracilis muscle flap. Plast Reconstr Surg. 2005;115(4):1110-1117.

17. Windhofer C, Brenner E, Moriggl B, Papp C. Relationship between the descending branch of the inferior gluteal artery and the posterior femoral cutaneous nerve applicable to flap surgery. Surg Radiol Anat. 2002;24: 253-257.

18. Wechselberger $G$, Schoeller $T$. The transverse myocutaneous gracilis free flap: A valuable tissue source in autologous breast reconstruction. Plast Reconstr Surg. 2004;114(1):69-73.

19. Schoeller T, Huemer GM, Wechselberger G. The transverse musculocutaneous gracilis flap for breast reconstruction: Guidelines for flap and patient selection. Plast Reconstr Surg. 2008;122(1):29-38.

20. Bodin F, Dissaux C, Dupret-Bories A, Schohn T, Fiquet C, Bruant-Rodier C. The transverse musculo-cutaneous gracilis flap for breast reconstruction: How to avoid complications. Microsurgery. 2016;36:42-48.

21. Wong C, Mojallal A, Bailey SH, Trussler A, Saint-Cyr M. The extended transverse musculocutaneous gracilis flap: Vascular anatomy and clinical implications. Ann Plast Surg. 2011;67(2):170-177.

22. Wechselberger $G$, Traintinger $H$, Larcher $L$, Russe E, Edelbauer M, Ensat $F$. Clinical applications of the transverse musculocutaneous gracilis flap for secondary breast reconstruction after simple mastectomy. Plast Reconstr Surg. 2016:137(1):19-28.

23. Werdin F, Haug DM, Amr A, Schoeller T. Double transverse myocutaneous gracilis free flaps for unilateral breast reconstruction. Microsurgery. 2016; 36:539-545.

24. Mathur BS, Tan SS, Bhat FA, Rozen WM. The transverse lumbar perforator flap: An anatomic and clinical study. J Plast Reconstr Aesthetic Surg. 2016; 69(6):770-776

25. Schaffer C, Guillier D, Raffoul W, Di Summa PG. Lumbar Perforator Flaps for Coverage of Extensive Defects with Osteomyelitis. Ann Plast Surg. 2021; 86(1):67-71.

26. Mujtaba B, Hanafy AK, Largo RD, Taher A, Madewell JE, Costelloe C, et al. The lumbar artery perforator flap: clinical review and guidance on image reporting. Clin Radiol. 2019;74(10):756-762.

27. Peters KT, Blondeel PN, Lobo F, Van Landuyt K. Early experience with the free lumbar artery perforator flap for breast reconstruction. J Plast Reconstr Aesthetic Surg. 2015;68(8):1112-1119.

28. Opsomer D, Stillaert F, Blondeel P, Van Landuyt K. The lumbar artery perforator flap in autologous breast reconstruction: Initial experience with 100 cases. Plast Reconstr Surg. 2018:142(1):1e-8e.

29. Haddock NT, Teotia SS. Lumbar Artery Perforator Flap: Initial Experience with Simultaneous Bilateral Flaps for Breast Reconstruction. Plast Reconstr Surg - Glob Open 2020;8(5):e2800.

30. Nahabedian MY, Patel K. Autologous flap breast reconstruction: Surgical algorithm and patient selection. J Surg Oncol. 2016;113:865-874.

31. Tachi M, Yamada A. Choice of flaps for breast reconstruction. Int J Clin Oncol. 2005;10:289-297. 